\title{
SRI LANKA AND THE COVID 19 CRISIS: STRATEGIES AND FUTURE CHALLENGES
}

\author{
Asantha Senevirathna* \\ *Lecturer, Department of Strategic Studies, General Sir John Kotelawala University, \\ Ratmalana,SriLanka,Email: asanthas@kdu.ac.lk
}

\begin{abstract}
COVID-19 pandemic has become a major crisis in 2020. The pandemic has claimed thousands of lives and is spreading a negative economic impact around the global economy. The pandemic has caused a devastating impact on human life in many of the countries without a clear distinction among developed or developing nations. Sri Lanka is facing the heat of the pandemic gradually since January and has taken various measures to combat the situation. The COVID-19 pandemic forwarded a greater challenge to Sri Lanka since the country has faced various disasters in the recent past and question marks remain about the government's response. The Sri Lankan government response to the current COVID-19 crisis has been largely successful and is ranked among the best responsive countries in the world. This paper discusses Sri Lanka's strategies in dealing with COVID-19 pandemic and possible future challenges related to the issue.
\end{abstract}

Keywords: pandemic-COVID-19 crisis-SriLanka - strategies - result - measures outcomes - challenges

\section{INTRODUCTION}

At present COVID-19 is continuing as a major pandemic that has infected and killed many people all around the world. Mostly the term pandemic widely used to describe the diseases that extend over a larger geographical area. Further, pandemics are mostly characterised by disease outbreaks that become widespread in the world as a result of the spread of it from human-to-human infection(Qiu, Rutherford, Mao \& Chu 2017). The impact of the current pandemic is creating challenges for policy makers around the world including Sri Lanka. There have been several viral infectious diseases that threaten the world in recent times. But, current COVID-19 pandemic can be seen as a much severe case in nature to those: 
While recent decades have witnessed a series of global public health challenges brought by widespread viral infections - the Severe Acute Respiratory Syndrome (SARS) outbreak in 2003, the Ebola virus pandemic from 2014 to 2016, and the Zika virus epidemic from 2015 to 2016, to name but a few - none of them are comparable in their geographical reach and socioeconomic impacts of Covid-19 (Chung, Zu \& Chang 2020).

Since its first reported in China late last year, the virus has spread to every continent and country except Antarctica. As of $29^{\text {th }}$ May 2019, the cases are rising daily in Europe, the Americas, and Africa with relative decrease is shown in many Asian countries.(Health Promotion Bureau 2020). All countries are adopting strategies to slow the spread of the virus by testing and treating of patients, conducting contact tracing, putting travel restrictions, quarantining of citizens, and prohibiting large gatherings such as sporting events, various concerts, and schooling. The pandemic is moving like a wave one that may yet crash on those least able to cope. The COVID-19 can be described as much more than a global crisis only related to health. Many of the world's large cities are deserted as its inhabitants are meant to stay indoors, due to the circumstances or by the government order. Across the globe, most of the shops, restaurants bars, and theatres are closed. This has created socio-economic problems all over the world. All over the world, people are losing jobs and their income, with no way to identify when normality will return. Many countries heavily dependent on tourism, have empty hotels and deserted beaches(UNDP 2020). Since early January 2020, the COVID-19 was started having an impact on Sri Lankan society with the news of rising deaths and cancellation of various events in countries around the world. Many Sri Lankans living abroad and were spreading the worsening situation in those countries to fellow Sri Lankans. The news of the rapid spread of the virus in many countries and its social-economic impact forwarded a challenge to Sri Lankan authorities to formulate strategies to face the challenge. Sri Lanka was facing a lockdown since mid of March 2020 creating various economic and social problems. The airports, schools and shops were closed creating a loss of jobs and livelihood for the people around the island. The parliamentary election that was scheduled to be held on last week of April was postponed due to the prevailing situation. But, in relative to many countries of the world, Sri Lanka has been successful in its strategy to contain the spread of the virus. It is important to identify what was the institutional structure that Sri Lanka had to face this type of emergency with its strengths and weaknesses. 
This study is focusing on what are the new structural and strategic changes that the Sri Lankan government undertook with the relevant stakeholders to face the challenges forwarded by COVID-19 pandemic. Finally, the study discusses the success of Sri Lankan strategies in facing COVID-19 pandemic.

\section{METHODS}

This study was a qualitative research that collected data using secondary sources. The researcher mainly used journal articles, and relevant websites to collect data for this study. The COVID-19 is an ongoing pandemic situation around the world including in Sri Lanka and study only focused on available information till $29^{\text {th }}$ of June 2020. The research philosophy was based on interpretivism where researcher incorporated his own viewpoint to available data in presenting ideas.

\section{DISCUSSION PART I: COVID-19 AND SRI LANKA}

The first person with the virus in Sri Lanka was identified on $27^{\text {th }}$ January 2020. A 43-year-old Chinese woman from the Hubei region in China who had come to Sri Lanka as a tourist was admitted to the National Institute of Infection Diseases (IDH) due to suspected patient and was found positive (Reuters 2020). The proper and specialised treatment of the patient at the counties main infection disease hospital resulted in her recovery. Later due to the tourist arrivals and Sri Lankans returning home mainly from European countries brought the virus into the country. The first Sri Lankan national with COVID-19 positive was identified in early March 2020, a male tour guide who was engaged in handling a group of tourists from Italy (Perera 2020). Further, a large number of Sri Lankans living in Italy arriving into the country due to the deteriorating situation in there tested positive for the virus. The increasing number of COVID-19 patients since March 2020 meant that the country going into a lockdown situation. In this background, the government took immediate action to prepare medical facilities in the county to face the situation. Mainly the new cases that found were people who arrived in the country from abroad and the people who had immediate contact with those, where mostly the close family members. According to Health Promotion Bureau (2020), as of $29^{\text {th }}$ May 2020, Sri Lanka has reported a total of 1530 COVID-19 cases in the country. Currently, there are 775 active cases while 745 has recovered and as of now, 10 deaths were reported due to the pandemic. Concerns about transmission within families and close relatives or contact persons led to 
the imposition of quarantine measures and even two-to three-week-long curfews in certain areas (Jayasuriya 2020).

At the micro-level, there were many socio-economic implications. Many people that were engaged in day to day earning has lost their main income. Further, the restrictions on movement meant that people were facing difficulty in acquiring essential goods and services. In this background, the government faced a challenge of implementing new strategies to provide support for maintaining day to day life of the people while preventing the spread of the virus within the society. In a special situation like this, better coordination becomes very important. The leadership of government meant vital among the medical sector, law enforcement, public service, and other relevant stakeholders under the to face the challenges posed by COVID-19.

\section{DISCUSSION II: SRI LANKA'S STRATEGY IN DEALING WITH COVID-19}

The gradual spreading of COVID-19 virus in the country forwarded a greater challenge to Sri Lanka as a country due to recent experience related to Easter Sunday Bombings. In April 2019, the Easter Sunday bombings claimed more than 250 lives that consisted both Sri Lankans and foreigners (Selvanayagam 2019).Sri Lanka as a country is still recovering from that devastating incident. In this background, the new president who came to power in via newly held election in January 2020 had to find and adopt a new strategy to face this new crisis. In recent times, Sri Lanka has faced various emergencies. The recent disasters were both natural and manmade. After the devastating Indian Ocean Tsunami that occurred in 2004, the government created a new institution called the Disaster Management Centre (DMC). The DMC and its functioning in recent disasters were largely not satisfactory. In this background, the present government had to decide and create a new structure and strategy to face the challenges posed by this new COVID-19 pandemic. The new president who came to power in January 2020 developed a new structure and strategy to face this new crisis. The president took action to form a National Operation Centre for Prevention of COVID-19 Outbreak (NOCPCO), co-chaired by the Honourable Minister of Health, Chief of Defence Staff and Commander of the Army, and the Director-General of Health Services (NOCPCO, 2020). As Vidanage (2020) highlights Sri Lanka's initial response to this new COVID-19 pandemic situation has been robust. The president immediately adopted crucial new strategies and it has come into fruition. The social 
distancing and enforced lockdowns in all over the country largely mitigated primary infection levels.

The state-level strategy to address the COVID-19 crisis had three segments. The political leadership, military and other defence establishments, and health sector and professionals can be identified as these three segments. The country was facing a general election with dissolved parliament since $02^{\text {nd }}$ March 2020, the new president Gotabaya Rajapaksa had to take the lead to provide much needed political support for the crisis. According to the Sri Lankan constitution, the president holds a powerful executive position in decision making in the country. In this background, President Gotabaya Rajapaksa was able to give the leadership to government ministries to carry out their tasks.

The second segment included medical professionals and the health sector in the country. Sri Lanka is one of the few countries with a welldeveloped public health sector among the developing countries of the world. After the finding of the first few Sri Lankans with the virus in early March, the medical professionals urged the government to implement lockdown measures immediately. The Government Medical Officers Association (GMOA), the main trade union of government medical doctors in the country, issued a letter addressed to the president asking shutdown all ports of entry (Airports and Harbours).Further, the GMOA suggested extending the already prevailing local new year public holidays to cover the entire week and prevent unnecessary travelling and gathering of people (GMOA 2020). The medical professional's strong suggestion had an enormous impact on the political leadership of the country to closedown the port of entry to the country and implement lockdown measures, as necessary. The GMOA asked the government to resort to China-type lockdowns of certain parts of Sri Lanka to curb the spread of COVID-19 (Kuruwita 2020). The ministry of health and its medical professionals continuously conducted a media campaign to educate the public on the nature of the COVID-19 and how to take preventive measures to contain the spread of the virus.

The military establishment in the country represented the third segment that of the COVID-19 response from Sri Lanka. The current Sri Lankan acting Chief of Staff of the military and army commander was given a co-chair position at the NOCPCO in the national strategy implementation level of facing the pandemic. The military and various related defence establishments such as police (which is also under the Ministry of Defence) 
undertook rapid actions and measures on preventing. Sri Lankan military intelligence played a vital role in collecting information and taking action on the infected people and the people that they had contacts (possible suspects due to contacts). The military's response was quick to the suspected people. The military with the coordination of police and health officials reached the suspected people overnight and took measures to quarantine the people. Sri Lanka army, navy and air force started 41 quarantine centres all over the country. The persons who arrived from abroad since $1^{\text {st }}$ of March 2020 and all the people who were suspected of having a connection to them was either taken to one of these quarantine centres or asked to self-quarantine at their homes under strict regulations (Farzan 2020). During the quarantine period, the military provided food and all necessary facilities to the people and anyone who was identified as COVID-19 patients were immediately sent to the hospitals dedicated to COVID-19 treatment in the country. Further, the military helped the police and other law enforcement agencies to maintain the lockdown measures all over the country.

The above mention triad was working cooperatively to address the pandemic and they specially created a mechanism to mobilise the grassroots level government officers to take actions in the smallest governance bodies in the country. The Grama Niladhari's (village officers) around the countries were used to collect data and approach people at the local level as of needs. Further, high-level government officials, military and police seek the assistance of Public Health Inspectors (PHI's) along with Grama Niladhar is to reach the suspected persons around the country. The grassroots level government officials were incorporated in local level coordinating meetings to collect valuable information to analyse the situation.

The government had to incorporate the private sector of the country into a strategic response. The co-operation of the private sector meant vital in facing the situation since it plays an important part in the socio-economic functions of the country. In the initial stage,the government did not allow the private sector hospitals to test suspected COVID-19 persons or to treat them. By early April,the government allowed private hospitals to conduct Polymerase chain reaction (PCR) tests on suspected people. However,the treatment of COVID-19 patient was only confined to specialized government hospitals. Further, the government permitted selected private supermarket chains and pharmacies to distribute food and medicine for the needy people based on online orders. The government regulated the activities of the 
private sector by imposing guidelines given by the medical professionals to prevent any chance of the spreading of the virus.

\section{RESULTS: MEASURING THE OUTCOME OF THE STRATEGIES}

Sri Lanka is considered to be an air and naval hub in the region of South Asia and closing its port of entry meant a large loss to the country's economy. But closing external connection and implementing a lockdown became a necessity to contain the spread of COVID-19 virus in the country. According to the report published by the Charted Management Accountants (CMA) Australia, Sri Lanka was ranked very high among the nations in the world based on the response to COVID-19 pandemic (CMA 2020). The GRID Index: Tracking the Global Leadership Response in the COVID-19 Crisis, published by the above authority, ranked Sri Lanka at $9^{\text {th }}$ place in the world. According to the report, Sri Lanka was the only developing country in the world which ranked among the top 10 countries. The report largely considered the good political leadership has been more critical. The report further highlighted that the countries which had weak political leadership in the fight against this pandemic as countries all over the world that struggles to prevent the spread of COVID-19 virus. In times of this sort of crisis, good leaders rally to nurture and protect their citizens. Great political leaders with strategic vision go beyond their national boundaries and unite the world in fostering global partnership and cooperation to work towards the common good of global citizen (CMA 2020). This report highlights that the current political leadership of Sri Lanka is comparatively successful in giving visionary leadership to fight COVID-19 situation in the country.

Sri Lanka has been lauded around the world for providing good health coverage at a low cost despite having a modest per capita income (Chapman \& Dharmaratne 2019).Sri Lanka's public health sector and its workers in different levels played an important role against the COVID-19 virus in the country. It was evident that even some of the developed countries with very good health facilities have not been able to cope with the pandemic due to its nature and as a developing country, Sri Lanka's efforts show a relative success. Further, 12.4 percent of Sri Lanka's population belongs to the elderly population of the country which is highly vulnerable to COVID-19 virus. In this background, the advice provided by the medical professionals in the country to government and public was instrumental in containing the spread of the virus. Sri Lanka with limited resources relative to the developed countries has performed well (Hewage 2020). Sri Lanka 
is long being recognized as a country that invested more on the health care system of the country. This strong health system has helped Sri Lanka to overcome challenges posed by crises in the country:

Health care is considered a basic human right in Sri Lanka, and, reflecting this priority, the government dedicates government tax revenues to ensure equitable access to all people in the country, regardless of whether they are a citizen. In particular, Sri Lanka has recognized the inherent market failures associated with financing health promotion and prevention related services, and has therefore prioritized investments in those areas. (Abeykoon 2019)

The world in general and the people who live in it for their own betterment is better off if they were to invest more money and resources with paying attention to the making of Common Goods for Health (CGH). Focusing on epidemiological surveillance investing in it that facilitates is important. These investments will provide rapid response to various infectious outbreaks that certainly is an important segment of a countries health sector (Savedoff 2019).

The heavy involvement of the military in the fight against COVID-19 pandemic in Sri Lanka has had a positive impact on the outcome. A pandemic like COVID-19 requires rapid action. Military as a well-organised segment of the society has the capacity, capability and the resources and they are able to run quarantine centres and maintain supply chains effectively all over the country. The public health sector in Sri Lanka that worked in close cooperation with the military of the country has shown positive results (Srinivasan 2020). In this background, the military has certainly played an important role in containing COVID-19 in the country.

Sri Lanka is facing a lockdown since mid of March 2020 creating various economic and social problems. The airports, schools and shops were closed creating a loss of jobs and livelihood for the people around the island. The parliamentary election that was scheduled to be held on last week of April was postponed due to the prevailing situation. But, in relative to many countries of the world, Sri Lanka has been successful in its strategy to contain the spread of the virus. The present success has resulted in a well-calculated gradual easing of the lockdown measures in the country. The government is now engaged in a process of normalizing and rebuilding the day to day life of the people in the country. Most of the countries in the world have failed in containing the spread of the COVID-19 virus. 
However, Sri Lanka relatively successful in containing the virus. But still due to the nature of the pandemic and the negative economic impact it has created challenges to the country.

\section{FUTURE CHALLENGES}

At present Sri Lanka is not reporting COVID-19 cases from the society but suspected persons in various quarantine centres. The government is gradually easing the lockdown measures to support the resumption of daily livelihood of the people. The government is further considering gradual reopening of the port of entries to the country targeting of economic activities. But when we consider the nature of the COVID-19 at any time the second wave remains a possibility. Sri Lankan government face the challenge of regaining the export market that had a negative impact due to COVID-19 and reopening the country for tourism baring a risk. Further, the government has the challenge of supporting domestic economic activities by providing incentives to affected entities and people. The region of South Asia and most of the other parts of the world is still showing a high number of COVID-19 cases. In this background, travelling from Sri Lanka and arrivals from those countries certainly create a dangerous situation. Thousands of Sri Lankan citizens working and living abroad is seeking permission to come back to the country. The government of Sri Lanka is now faced with the challenge to bring those citizens back to the country and most importantly quarantine those people before allowing them to go to the society. The non-availability of a proper vaccine anywhere in the world certainly have an impact on normalising life in Sri Lanka. In this background, the government of Sri Lanka need to continue testing every person that arrives from abroad under quarantine measure that the country was already maintaining.

\section{CONCLUSION}

COVID-19 pandemic has become a major crisis in the world. Thousands of people have lost their lives and most of the citizens of the world are facing a lockdown situation bringing a negative impact on the global economy and the government of Sri Lanka is adopting various strategies to contain the spread of the virus. Among the strategies adopted by the Sri Lankan government to response COVID-19 crisis, it has given priority to three segments. The political leadership, Military and other defence establishments, and Health sector and professionals can be identified as these three segments. The new president of Sri Lanka with the executive powers 
vested on him is giving the political leadership to the crisis. For a long time, Sri Lanka is been identified as a country with a high standard public health care system in the world. The health professionals continuously provide valuable advice to the government and the public on how to contain the virus. The long term investments in public health care have benefited Sri Lanka in facing this COVID-19 crisis compared to many other countries. The heavy involvement of the military in response to COVID-19 can be seen as the third segment of governments strategy to face the crisis. The military is operating many quarantine centres all over the island and its intelligence has been able to identify suspected people with COVID-19 and guide them to quarantine. The availability of resources and ability of the military to respond quickly has benefited the country's to fight against COVID-19. Further, the inclusion of grassroots level government officials and the private sector in activities has strengthened the fight against COVID-19. According to international indicators, Sri Lanka has archived better results on containing the virus. The country is now gradually lifting its lockdown measures. But challenges remain considering the nature of COVID-19 since it can come again to the country from outside. The challenge will remain until a proper vaccine to be found. Further, like any other country in the world,Sri Lanka is faced with the challenge of revamping its economy. Long term investments on public health, the effective implementation of the lockdown measure, effective use of special capabilities of the military, effective coordination and implementation of activities within government officials from both top and grassroots levels, and Government working closely with the private sector under special regulations have contributed to a positive outcome in Sri Lanka's fight against COVID-19 pandemic that other countries in the region and elsewhere can share.

\section{REFERENCES}

Abeykoon, P. (2019). Financing common hoods for health: Sri Lanka. Health System \&Reform, 5(4): 397-401. (doi https://doi.org/10.108 0/23288604.2019.1655358)

Chapman, A.R. \& Dharmaratne, S.D. (2020). Sri Lanka and the possibilities of achieving universal health coverage in a poor country. Global Public Health: An International Journal for Research, Policy and Practice, 14(2): 271-283. (doihttps://doi.org/10.1080/17441692.20 18.1501080) 
Chung, C.K.L. Xu, J. \& Chang, M. (2020). Geographies of Covid-19: How space and virus shape each other. Asian Geographer. https://doi.or g/10.1080/10225706.2020.1767423.

CMA Australia (2020).GRID Index: Tracking the global leadership response in the COVID-19 crisis. https:/www.cmawebline.org/ ontarget/grid-index-tracking-the-global-leadership-response-inthe-covid-19-crisis/ (Accessed: 26.05.2020)

Farzan, Z. (2020 May 07). 41 Military operated quarantine facilities Sri Lanka to combat COVID-19. News $1^{\text {st }}$. https://www.newsfirst. 1k/2020/05/07/41-military-operated-quarantine-facilities-srilanka-to-combat-covid-19/ ( Accessed: 26.05.2020)

GMOA (2020). GMOA Proposes drastic measures to control COVID19 pandemic. https://www.gmoa.lk/wp-content/uploads/2020/03/ GMOA-Proposes-drastic-measures-to-control-COVID19pandemic..pdf (Accessed: 26.05.2020)

Health Promotion Bureau (2020). COVID-19 Situation Report: 2020-May29. https://www.hpb.health.gov.lk/en.

Hewage, K. (2020). Sri Lanka's fight against COVID-19. South Asian Voices. https://southasianvoices.org/covid-19-the-situation-in-srilanka/. Accessed: 27.05.2020

Jayasuriya, D. (2020). Covid-19: the Sri Lankan response. The Round Table: The Commonwealth Journal of International Affairs. https:// doi.org/10.1080/00358533.2020.1757281)

Kuruwita, R. (2020, March 16). GMOA recommends China-type lockdowns. The Island. http:/www.island.lk/index.php?page_ cat $=$ article-details\&page $=$ article-details\&code_title $=220461$.

Morens, D.M., Folkers, G. K. \& Fauci, A. S. (2009). What is a Pandemic?. The Journal of Infectious Diseases, 200(7): 1018-1021. https://doi. org/10.1086/644537.

NOCPCO (2020). Home: National operation centre for prevention of COVID - 19 outbreak. https://alt.army.lk/covid19/ (Accessed: 29.05.2020) 
Perera, M.M. (2020, March 11). First local coronavirus case in Sri Lanka. Asia News. http://www.asianews.it/news-en/First-localcoronavirus-case-in-Sri-Lanka-49529.html

Qiu,W. S., Rutherford, W.S.A., Mao, A. \& Chu, C. (2017). The Pandemic and its Impacts, Health, Culture and Society, 9(10): 1-11. doi $10.5195 /$ hcs. 2017.221

Reuters (2020). Sri Lanka confirms first case of coronavirus: health official. https://www.reuters.com/article/us-health-china-srilanka/sri-lanka-confirms-first-case-of-coronavirus-health-officialidUSKBN1ZQ1WF. Accessed: 26.05.2020)

Savedoff, W.D. (2019). Why Do Societies Ever Produce Common Goods for Health?, 5(4): 402-405. https://doi.org/10.1080/23288604.201 9.1655982)

Selvanayagam, S.S. (2019, October 03). Easter Sunday attacks SC grants leave to proceed $12 \mathrm{FR}$ petitions. Daily Mirror. http://www. dailymirror.lk/front_page/Easter-Sunday-attacks-SC-grantsLeave-to-proceed-12-FR-Petitions/238-175526.

Srinivasan, M. (2020, April 15).COVID-19: Sri Lankan military is helping the country fight the pandemic. The Hindu. https://www.thehindu. $\mathrm{com} /$ news/international/covid-19-sri-lankan-military-is-helpingthe-country-fight-the-pandemic/article31350778.ece.

UNDP (2020). COVID-19 pandemic: Humanity needs leadership and solidarity to defeat the coronavirus. https://www.undp.org/content/ undp/en/home/coronavirus.html. (Accessed: 26.05.2020).

Vidanage, H. (2020, March 30). Is Sri Lanka ready for Covid-19 effect?. Daily Mirror. http://www.dailymirror.lk/print/opinion/Is-SriLanka-ready-for-Covid-19-effect/172-185859. 